\title{
Search for methylation-sensitive amplification polymorphisms in mutant figs
}

\author{
M.G.F. Rodrigues ${ }^{1}$, A.B.G. Martins ${ }^{2}$, B.W. Bertoni ${ }^{3}$, A. Figueira ${ }^{4}$ and \\ S. Giuliatti ${ }^{1}$ \\ ${ }^{1}$ Departamento de Genética, Faculdade de Medicina de Ribeirão Preto, \\ Universidade de São Paulo, Ribeirão Preto, SP, Brasil \\ ${ }^{2}$ Departamento de Produção Vegetal, \\ Faculdade de Ciências Agrárias e Veterinária, \\ Universidade Estadual Paulista, Jaboticabal, SP, Brasil \\ ${ }^{3}$ Departamento de Biotecnologia de Plantas, \\ Universidade de Ribeirão Preto, Ribeirão Preto, SP, Brasil \\ ${ }^{4}$ Centro de Energia Nuclear na Agricultura, \\ Escola Superior de Agricultura "Luiz de Queiroz", \\ Universidade de São Paulo, Piracicaba, SP, Brasil \\ Corresponding author: M.G.F. Rodrigues \\ E-mail: gabrielafontanetti@hotmail.com
}

Genet. Mol. Res. 12 (3): 2267-2280 (2013)

Received August 21, 2012

Accepted December 14, 2012

Published July 8, 2013

DOI http://dx.doi.org/10.4238/2013.July.8.8

\begin{abstract}
Fig (Ficus carica) breeding programs that use conventional approaches to develop new cultivars are rare, owing to limited genetic variability and the difficulty in obtaining plants via gamete fusion. Cytosine methylation in plants leads to gene repression, thereby affecting transcription without changing the DNA sequence. Previous studies using random amplification of polymorphic DNA and amplified fragment length polymorphism markers revealed no polymorphisms among select fig mutants that originated from gammairradiated buds. Therefore, we conducted methylation-sensitive amplified polymorphism analysis to verify the existence of variability due to epigenetic DNA methylation among these mutant selections compared to the main cultivar 'Roxo-de-Valinhos'. Samples of
\end{abstract}


genomic DNA were double-digested with either HpaII (methylation sensitive) or MspI (methylation insensitive) and with EcoRI. Fourteen primer combinations were tested, and on an average, non-methylated CCGG, symmetrically methylated CmCGG, and hemimethylated hmCCGG sites accounted for $87.9,10.1$, and $2.0 \%$, respectively. MSAP analysis was effective in detecting differentially methylated sites in the genomic DNA of fig mutants, and methylation may be responsible for the phenotypic variation between treatments. Further analyses such as polymorphic DNA sequencing are necessary to validate these differences, standardize the regions of methylation, and analyze reads using bioinformatic tools.

Key words: DNA methylation; Molecular marker; Mutation analysis; Plant breeding; Epigenetic inheritance

\section{INTRODUCTION}

Brazil is the major producer of figs (Ficus carica) in South America, and three States are noteworthy for their fig production: Rio Grande do Sul for fig production for industrial purposes, São Paulo for in natura fig production, and Minas Gerais for fig production for both industrial and in natura purposes. Fig tree cultivation in Brazil is based exclusively on a single cultivar, 'Roxo-de-Valinhos', which is characterized by high vigor and productivity (Pereira and Nachtigal, 1999).

Fig tree improvement programs that use conventional procedures to obtain new cultivars are rare in many countries, especially owing to 1) the low genetic variability associated with fig trees and 2) the difficulty in obtaining plants via gamete fusion, as the wasp Blastophaga psenes, which is responsible for the natural pollination of fig trees, is not found in Brazil because of the weather conditions (Ferreira et al., 2009).

Epigenetic variation describes molecular events responsible for the modulation of gene expression without changes in DNA sequences (Bird, 2007). These variations may be induced in response to stimuli and may persist after the removal of a stimulus, being inherited via vegetative propagation without permanent changes in the genotype (Borém, 1997). The main known cause of epigenetic change is methylation, which is the addition of methyl groups to cytosine bases in DNA located before and near guanine bases (Haines et al., 2001; Dodge et al., 2002). According to Bernstein et al. (2007), this type of epigenetic variation has been associated with the regulation of gene expression, genome defense, cellular differentiation, chromatin inactivation, and genomic imprinting.

The methylation-sensitive amplified polymorphism (MSAP)-polymerase chain reaction (methylation-sensitive arbitrarily primed polymerase chain reaction) technique developed by Reyna-López et al. (1997) is an adaptation of amplified fragment length polymorphism (AFLP) analysis and has proven to be a powerful tool for analyzing DNA methylation. The MSAP technique has been applied to study $\mathrm{CpG}$ methylation in the genomes of rice (Ashikawa, 2001) and banana (Baurens et al., 2003); to characterize methylation changes associated with micropropagated banana (Peraza-Echeverria et al., 2001) and apple (Li et al., 2002); to analyze the somaclonal variation of palm oil (Matthes et al., 2001); to analyze wheat vernal- 
ization (Sherman and Talbert, 2002); to analyze the degree of cytosine methylation during the germination of sweet pepper seeds (Portis et al., 2004); to investigate the resistance of rice to bacterial blight (Sha et al., 2005); to investigate genes differentially methylated in tomato after tomato yellow leaf curl Sardinia virus infection (Mason et al., 2008); and to examine various stages of development in Arabidopsis thaliana (Ruiz-Garcia et al., 2005) and among A. lyrata and its parent species (Beaulieu et al., 2009).

Joyce and Cassells (2002) determined the cytosine methylation status of DNA in in vitro-developed microplants with various leaf morphologies by using AFLP marker analysis with methylation-sensitive restriction enzymes to test the hypothesis that DNA methylation could be used to characterize differences between treatments. While attempting to improve fig trees, Rodrigues et al. (2012a) used cuttings of the cultivar 'Roxo-de-Valinhos' irradiated with gamma rays at a dose of 30 Gy to show that plants could be selected based on unique morphological characteristics that differed from those of controls. The selected characteristics included elongated fruit shape; elongated peduncle, which facilitates harvesting and increases the shelf life of fruits; large fruit size; and large fruit with a closed ostiole, which reduces the incidence of agricultural pest infestation and prevents fruit depreciation.

However, polymorphisms in these irradiated selections were not identified in fig samples evaluated using random amplification of polymorphic DNA and AFLP analyses, that is, genetic modification was absent, suggesting that epigenetic changes caused by gamma irradiation occurred between treatments (Rodrigues et al., 2012b). Given these findings, the aim of this study was to verify the existence of variability related to epigenetic DNA methylation of mutant fig selections by comparing them with the primary commercial cultivar 'Roxo-deValinhos' using MSAP analysis.

\section{MATERIAL AND METHODS}

The experiment was conducted at Faculdade de Medicina de Ribeirão Preto (São Paulo, Brazil) in partnership with Universidade de Ribeirão Preto using the leaves of 5 fig selections. The specimens consisted of cuttings irradiated with gamma rays at the Energy Nuclear Center in Agriculture (Piracicaba, Brazil). Five irradiated plants considered to be mutants were used (Rodrigues et al., 2012a); these selections were compared to one another and to the cultivar 'Roxo-de-Valinhos', which served as a control.

Young leaves without spots or perforations were collected and washed under running water, and their veins were removed. The extraction of total genomic DNA from plant tissues was performed according to a modified cetyltrimethylammonium bromide technique.

To detect MSAP, we performed two digestions simultaneously for each sample of genomic DNA. In the 1st reaction, 250 ng genomic DNA was digested using the One-Phor-All Buffer (Amersham Pharmacia Biotech) containing 5 U EcoRI restriction enzyme (New England Biolabs $^{\circledR}$, Inc.) and $5 \mathrm{U} M s p I$, a methylation-insensitive restriction enzyme (New England Biola$\mathrm{bs}^{\circledR}$, Inc.), in a final volume of $20 \mu \mathrm{L}$. The 2 nd digestion was conducted using the methylation-sensitive restriction enzyme HpaII (New England Biolabs ${ }^{\circledR}$, Inc.) instead of the MspI isoschizomer. The DNA fragments were digested and ligated to EcoRI (5'-CTCGTAGACTGCGTACC-3'/3'CATCTGACGCATGGTTAA-5') and HpaII/MspI adapters (5'-GATCATGAGTCCTGCT-3'/3'AGTACTCAGGACGAGC-5') using T4 DNA ligase (New England Biolabs ${ }^{\circledR}$, Inc.). The binding reaction was performed at $23^{\circ} \mathrm{C}$ for $3 \mathrm{~h}$. 
After pre-amplification using the pre-selective primers E+1 (5'-GACTGCGTACCAAT $\left.\mathrm{TC}+\mathrm{A}-3^{\prime}\right)$ and $\mathrm{HM}+1\left(5^{\prime}-\mathrm{ATCATGAGTCCTGCTCGG}+\mathrm{C}-3^{\prime}\right)$, the primers $\mathrm{E}+3\left(5^{\prime}-\mathrm{GACTG}\right.$ CGTACCAATTC+ANN-3') and HM+3 (5'-ATCATGAGTCCTGCTCGG+CNN-3'), where $\mathrm{NN}$ can be AC, AG, CA, CT, CC, CG, GC, or GG, were used for selective amplification following the protocols of Reyna-López et al. (1997). The selective amplification reactions were performed in a thermocycler with the following program: 12 cycles of $94^{\circ} \mathrm{C}$ for 30 $\mathrm{s}, 65^{\circ} \mathrm{C}$ for $30 \mathrm{~s}$, and $72^{\circ} \mathrm{C}$ for $1 \mathrm{~min} ; 22$ cycles of $94^{\circ} \mathrm{C}$ for $30 \mathrm{~s}, 56^{\circ} \mathrm{C}$ for $30 \mathrm{~s}$, and $72^{\circ} \mathrm{C}$ for $1 \mathrm{~min}$; and a final extension at $72^{\circ} \mathrm{C}$ for $2 \mathrm{~min}$. The 14 primer combinations used are shown in Table 1.

Table 1. Combinations of primers used for MSAP analysis.
\begin{tabular}{lllclc}
\hline Combination & Primer EcoRI + A & Primer HM + C & Combination & Primer EcoRI + A & Primer HM + C \\
\hline 1 & E + AG & HM + CAT & 8 & E + ATT & HM + CG \\
2 & E + AT & HM + CAG & 9 & E + AGT & HM + CAT \\
3 & E + AGT & HM + CTC & 10 & E + AGT & HM + CTA \\
4 & E + AG & HM + CTA & 11 & E + AC & HM + CAG \\
5 & E + AA & HM + CGT & 12 & CTA \\
6 & E + ATC & HM + CAG & 13 & E + AG & HM + CTT \\
7 & E + AC & HM + CTT & E + AA & HM + CG \\
\hline
\end{tabular}

The selective amplification products were separated on $6 \%$ polyacrylamide gels, and the bands were visualized with silver nitrate. Visualization of the samples after electrophoresis was performed with visual reading followed by photo-documentation of the plates.

In the plate analysis, methylation of the internal cytosine (CmCGG 5'-3') was indicated when bands present in the EcoRI $+M s p I$ reaction were absent in the EcoRI $+H p a \mathrm{II}$ reaction (Figures 1-3, black arrows). When bands present in the EcoRI + HpaII reaction were absent in the EcoRI $+M s p$ I reaction (see Figures 1-3, red arrows), the external cytosine of the DNA chain was methylated (5'-mCCGG-3'), which was considered hemimethylation (McClelland et al., 1994).

\section{RESULTS}

In the present study, MSAP analyses were performed to investigate the existence of regions with methylation patterns that differed between polymorphisms in mutant fig plants, thus characterizing their epigenetic distinction. Profiles of DNA amplified through MSAP analysis using 14 primer combinations were generated from the genomic DNA of selected fig mutants, which were originally derived from cuttings of the 'Roxo-de-Valinhos' cultivar after their buds were irradiated with gamma rays.

A total of 553 amplified fragments were obtained, 56 of which displayed different methylation patterns between treatments. Of the 14 pairs of primers tested, $100 \%$ exhibited polymorphic bands after digestion with the 2 enzymes tested, demonstrating that differential methylation occurred in the genomic material tested as shown in Figures 1-7. Unmethylated CCGG (bands common to both enzymes), symmetrically methylated CmCGG (bands present in DNA digested with MspI but not with HpaII), and hemimethylated hmCCGG (bands present in DNA digested with HpaII but not with $M s p \mathrm{I}$ ) comprised 88, 10, and $2 \%$ of the total amplification products, respectively. 


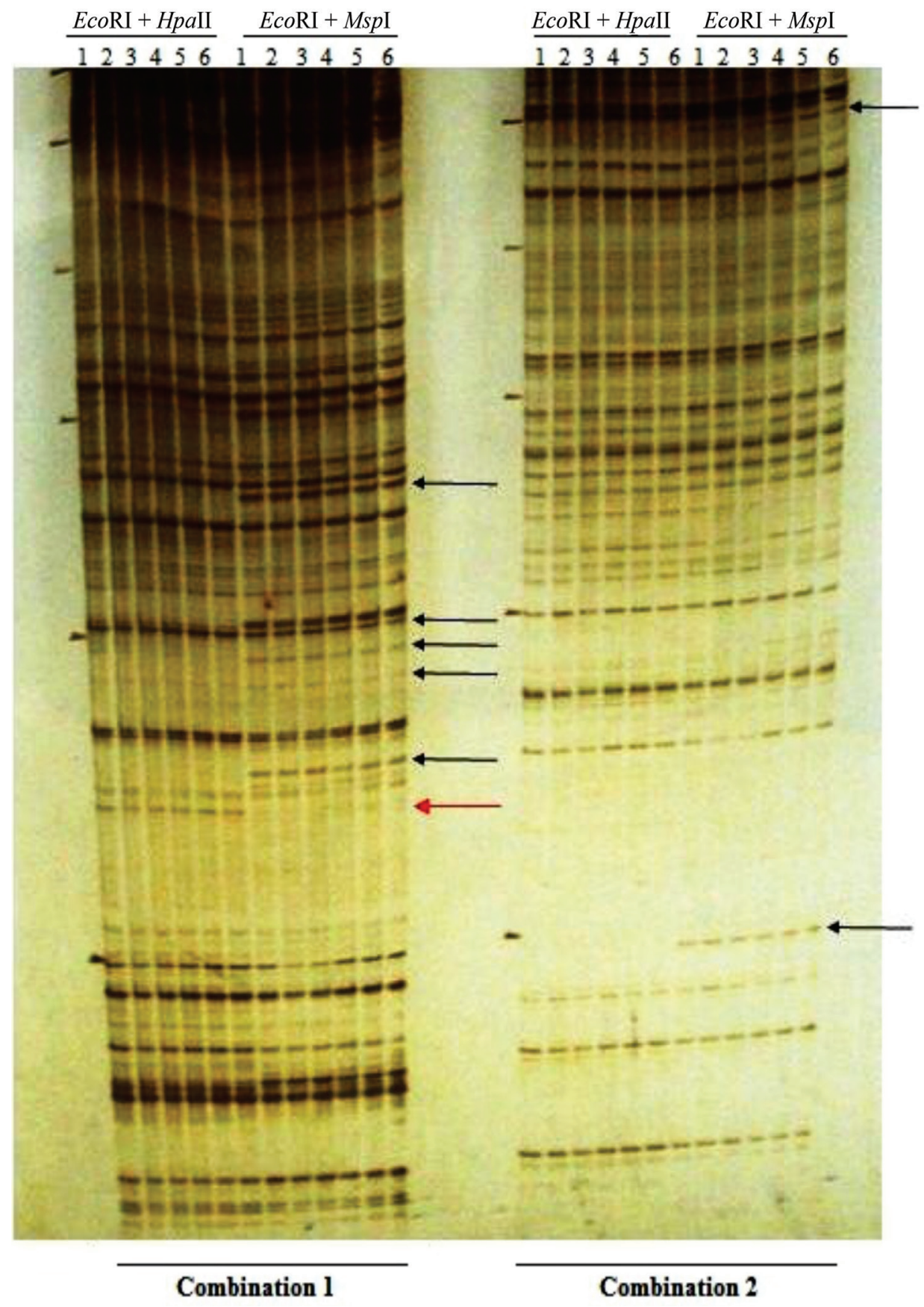

Figure 1. Amplification products using primer combinations 1 and 2 for fig mutants (Ficus carica L.) irradiated with gamma rays and the control 'Roxo-de-Valinhos' on $6 \%$ polyacrylamide gels. Numbers 1-6 refer to the following genotypes: lane $1=$ 'Roxo-de-Valinhos'; lane $2=$ PI 440; lane $3=$ PI 433; lane $4=$ PI 189; lane $5=$ PI 214; lane $6=$ PI 301 . 


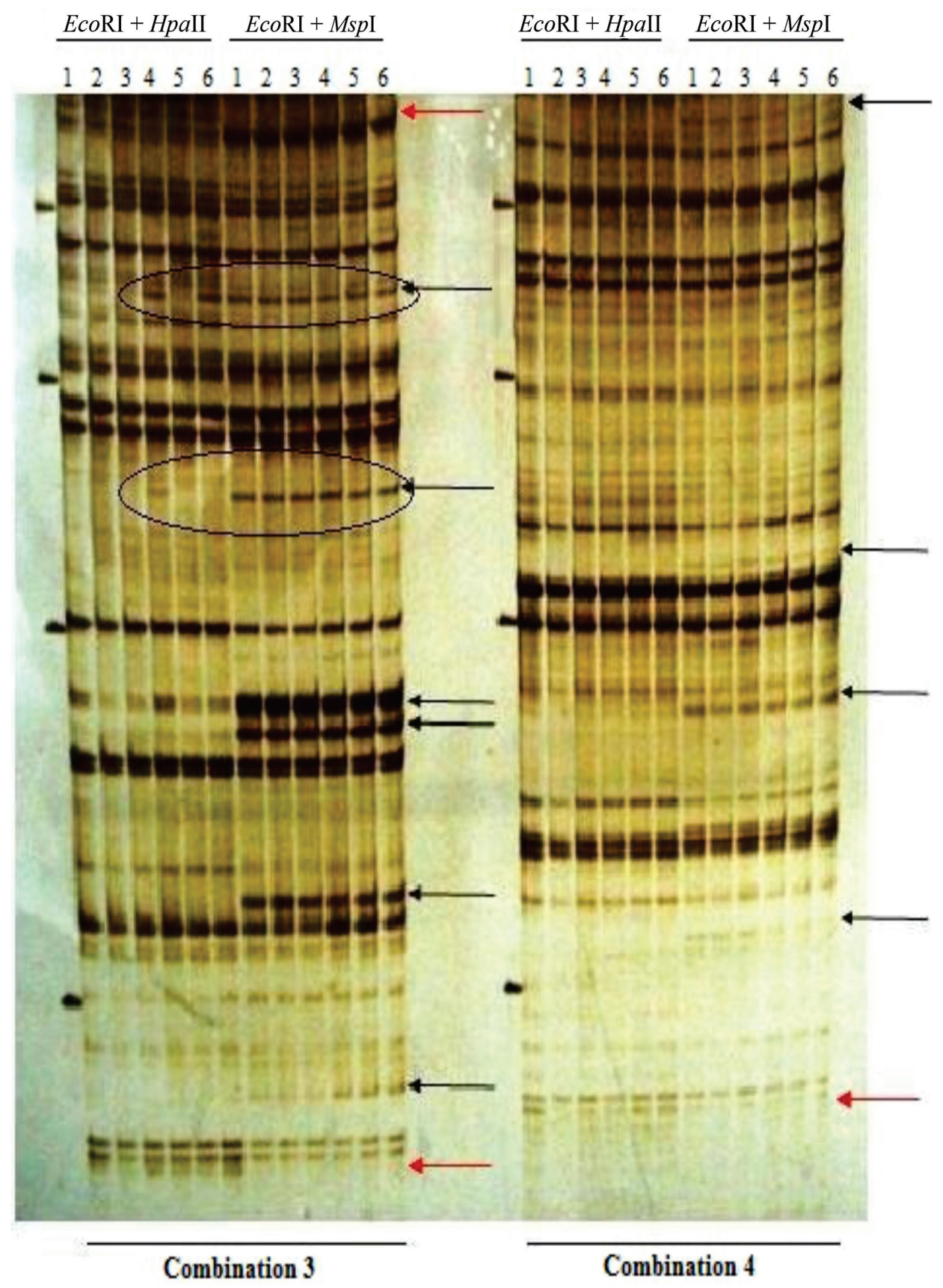

Figure 2. Amplification products using primer combinations 3 and 4 for fig mutants (Ficus carica L.) irradiated with gamma rays and the control 'Roxo-de-Valinhos' on $6 \%$ polyacrylamide gels. Numbers 1-6 refer to the following genotypes: lane $1=$ 'Roxo-de-Valinhos'; lane $2=$ PI 440; lane $3=$ PI 433; lane $4=$ PI 189; lane $5=$ PI 214; lane $6=$ PI 301 


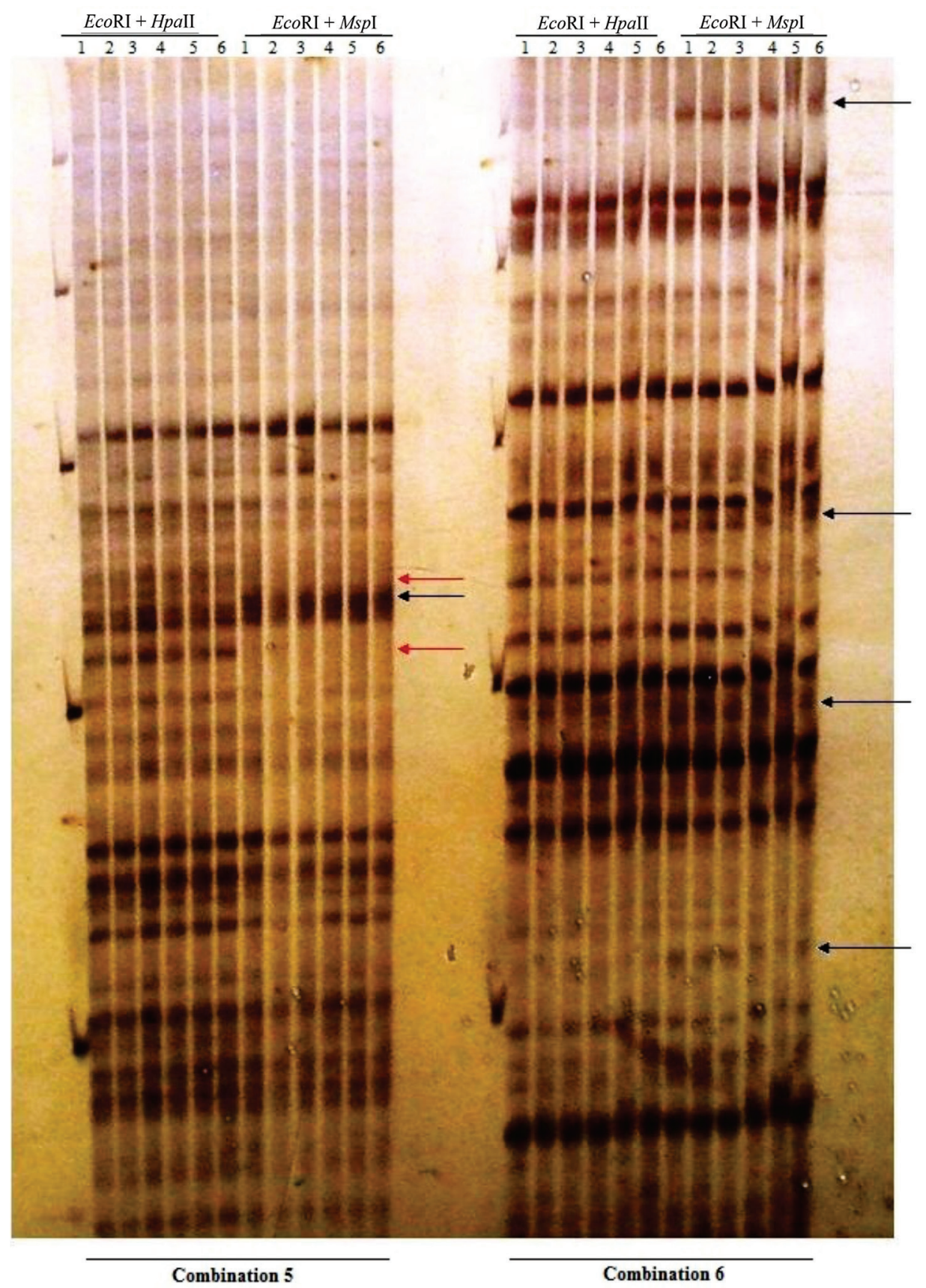

Figure 3. Amplification products using primer combinations 5 and 6 for fig mutants (Ficus carica L.) irradiated with gamma rays and the control 'Roxo-de-Valinhos' on $6 \%$ polyacrylamide gels. Numbers 1-6 refer to the following genotypes: lane 1 = 'Roxo-de-Valinhos'; lane 2 = PI 440; lane 3 = PI 433; lane 4 = PI 189; lane 5 = PI 214; lane $6=$ PI 301 . 


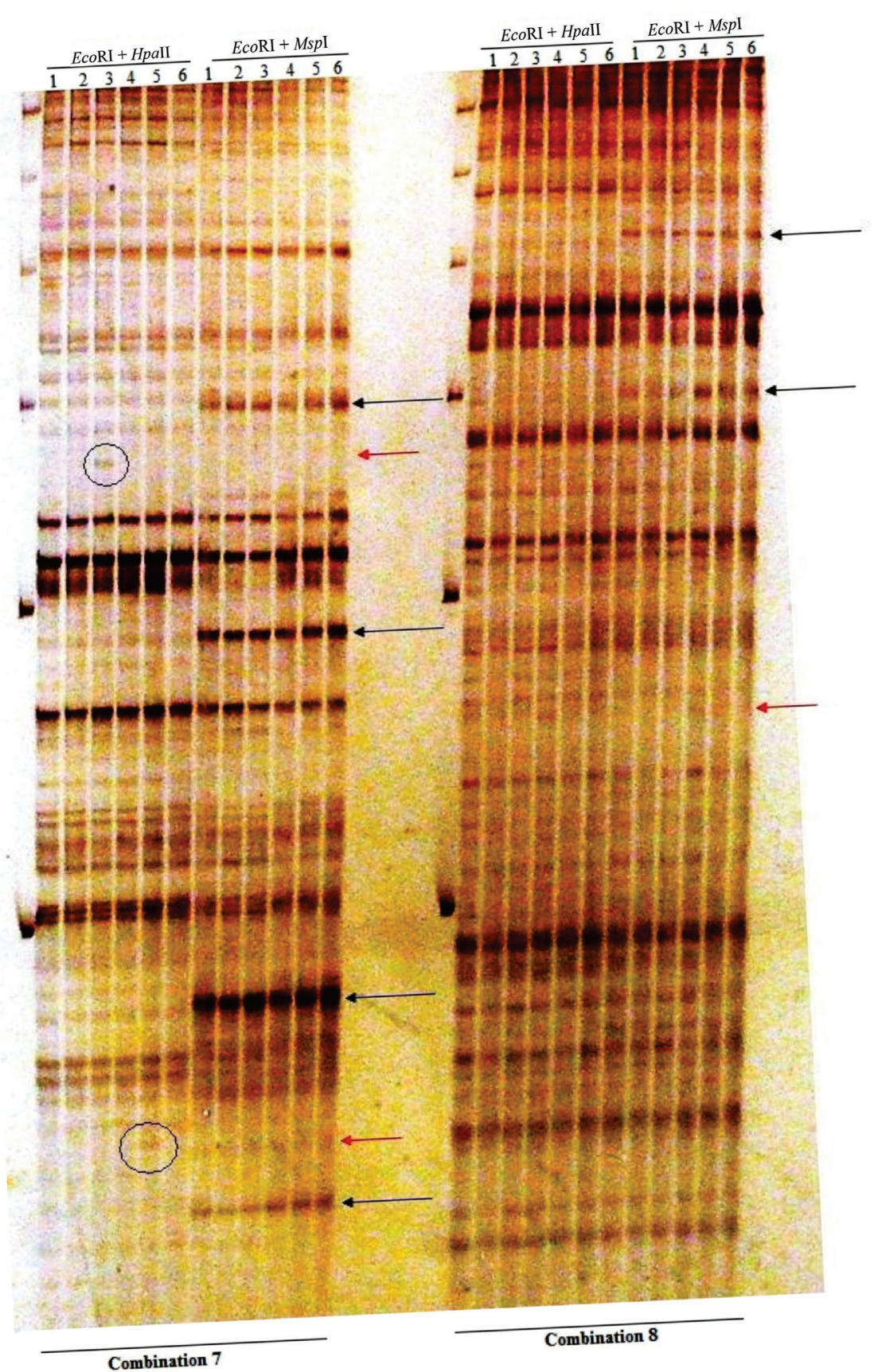

Figure 4. Amplification products using primer combinations 7 and 8 for fig mutants (Ficus carica L.) irradiated with gamma rays and the control 'Roxo-de-Valinhos' on $6 \%$ polyacrylamide gels. Numbers 1-6 refer to the following genotypes: lane $1=$ 'Roxo-de-Valinhos'; lane $2=$ PI 440; lane $3=$ PI 433; lane $4=$ PI 189; lane $5=$ PI 214; lane $6=$ PI 301 


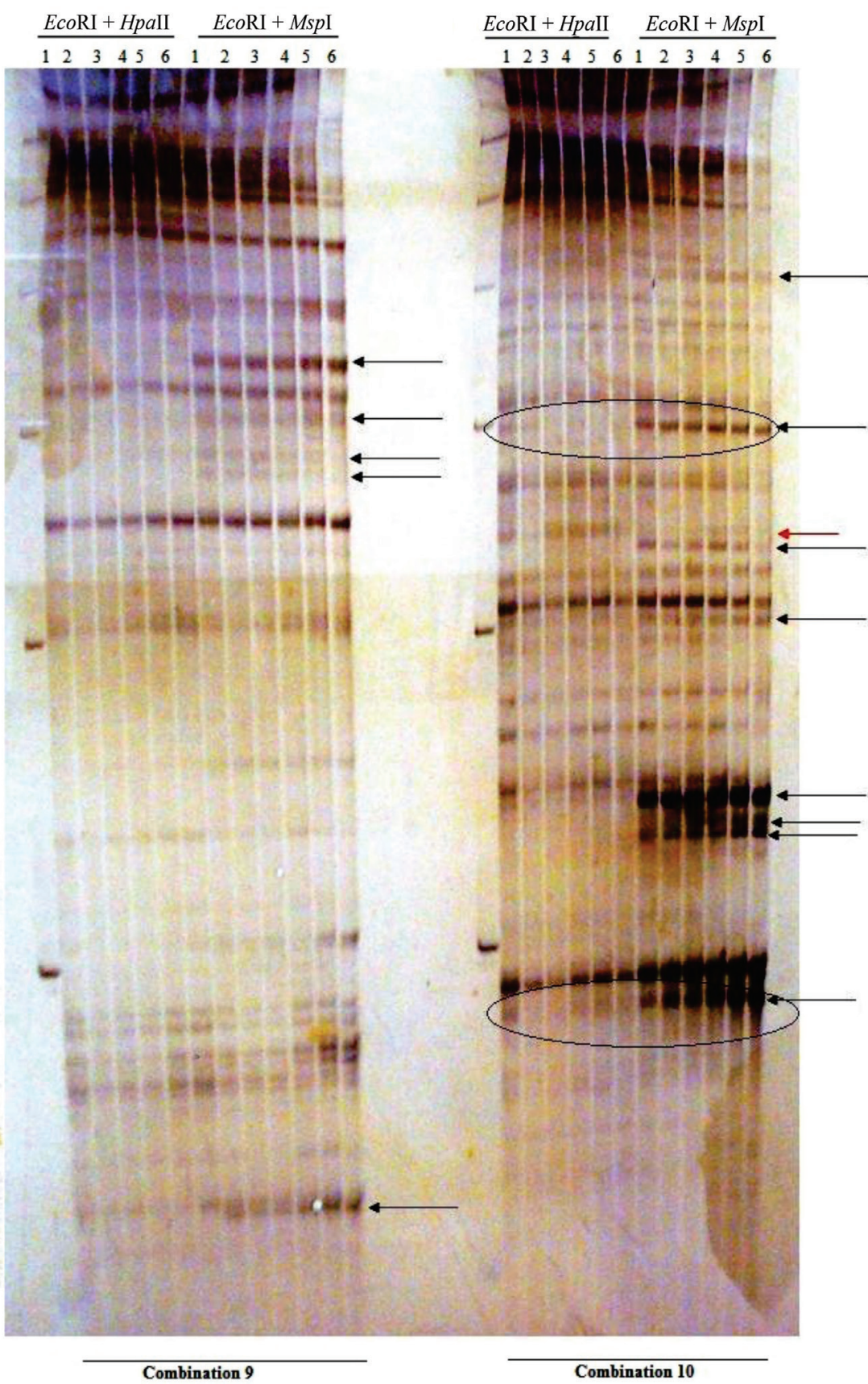

Figure 5. Amplification products using primer combinations 9 and 10 for fig mutants (Ficus carica L.) irradiated with gamma rays and the control 'Roxo-de-Valinhos' on $6 \%$ polyacrylamide gels. Numbers 1-6 refer to the following genotypes: lane $1=$ 'Roxo-de-Valinhos'; lane $2=$ PI 440; lane $3=$ PI 433; lane $4=$ PI 189; lane $5=$ PI 214; lane $6=$ PI 301 . 


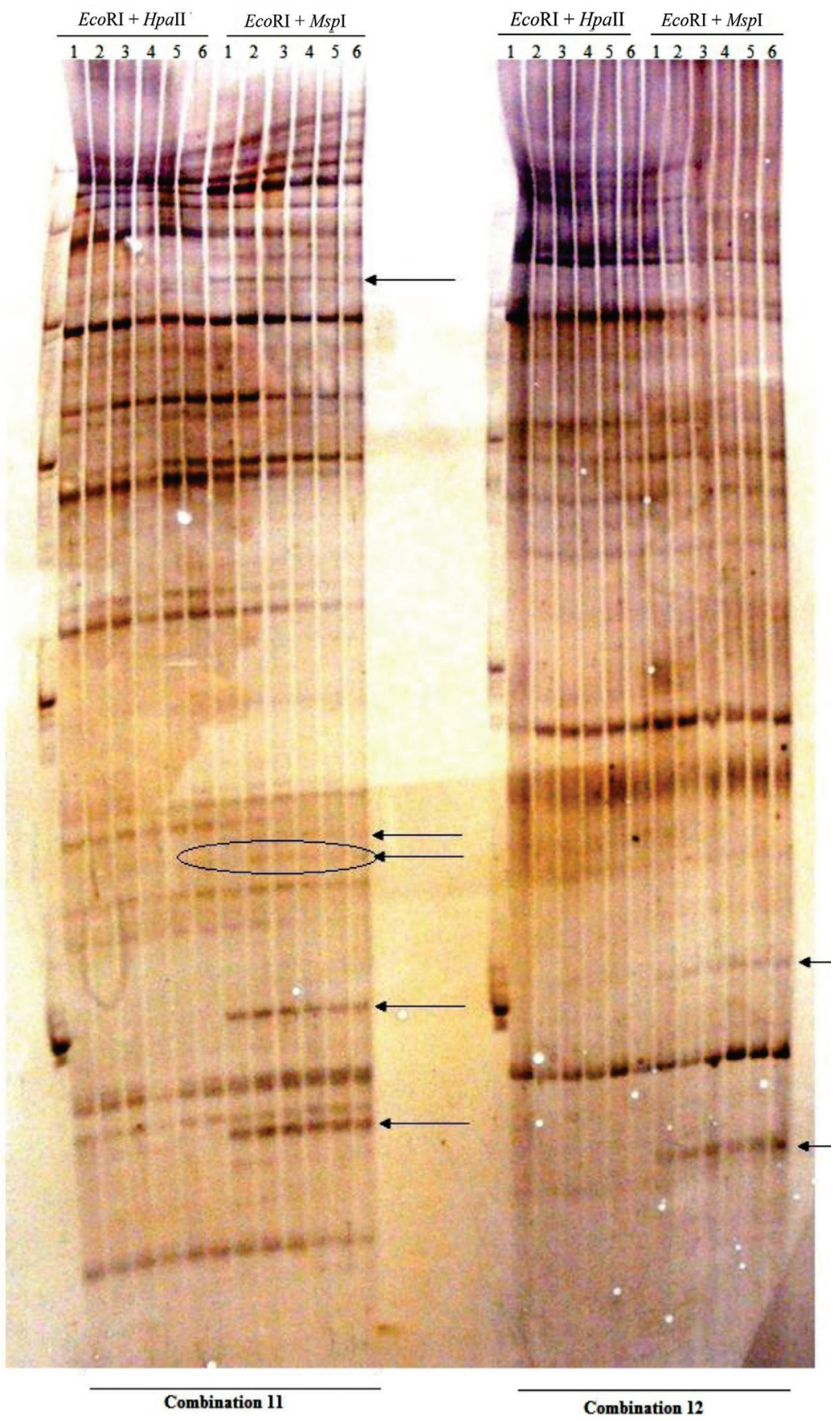

Figure 6. Amplification products using primer combinations 11 and 12 for fig mutants (Ficus carica L.) irradiated with gamma rays and the control 'Roxo-de-Valinhos' on $6 \%$ polyacrylamide gels. Numbers 1-6 refer to the following genotypes: lane 1 = 'Roxo-de-Valinhos'; lane 2 = PI 440; lane 3 = PI 433; lane 4 = PI 189; lane 5 = PI $214 ;$ lane $6=$ PI 301 


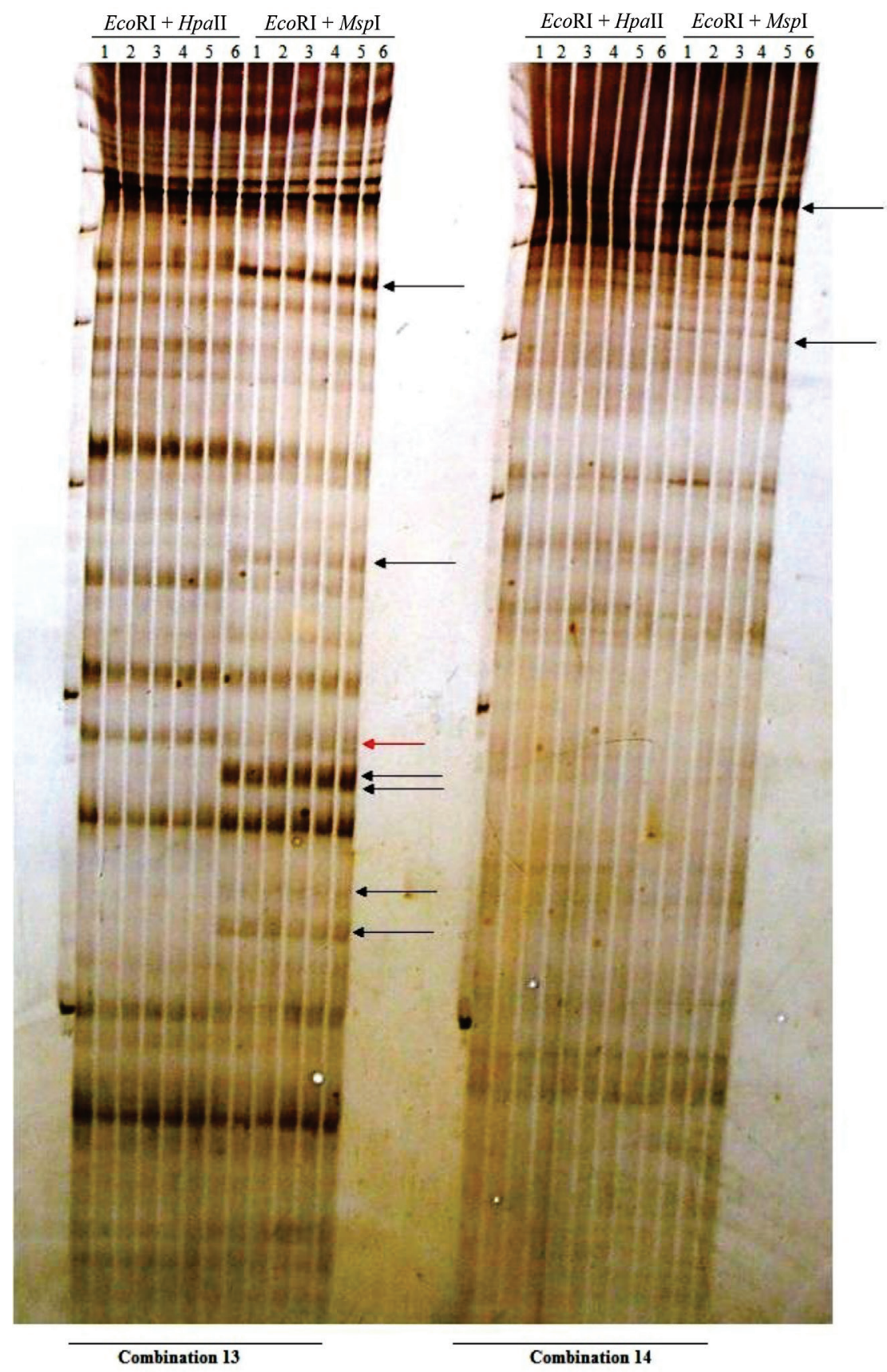

Figure 7. Amplification products using primer combinations 13 and 14 for fig mutants (Ficus carica L.) irradiated with gamma rays and the control 'Roxo-de-Valinhos' on $6 \%$ polyacrylamide gels. Numbers 1-6 refer to the following genotypes: lane $1=$ 'Roxo-de-Valinhos'; lane $2=$ PI 440; lane $3=$ PI 433; lane $4=$ PI 189; lane $5=$ PI 214 ; lane $6=$ PI 301 
Similar proportions of symmetrical methylated CCGG sites have been observed using approaches described by Ashikawa (2001) for rice (16.3\%), Peraza-Echeverria et al. (2001) for micropropagated banana plants (23\%), and Jaligot et al. (2004) for palm specimens. Jaligot et al. (2004) observed symmetrically methylated and hemimethylated sites in 14.7 and $4.1 \%$ of palm specimens, respectively.

Regarding the polymorphisms among treatments, a variation in the methylation pattern, which occurred with primer combinations $3,7,10$, and 11, was observed, as displayed in focus by circles in Figures 2,4,5, and 6. This variation suggests that the individuals studied are epigenetically different from one another, as each treatment resulted in a distinct variety of fig, particularly with regards to treatment 4 , which was superior to the 'Roxo-de-Valinhos' cultivar in all phenotypic characteristics evaluated (Rodrigues et al., 2009).

However, 'Roxo-de-Valinhos', which served as a control, was also methylated at all methylation sites using every combination except 10 . The presence of the methylated sites in the control and some unmethylated individuals suggests a process of methylation in the genomic material referred to as DNA demethylation. This process is an inverse process to methylation and is reversible.

Accordingly, with combination 7, a single hemimethylated polymorphic band was observed in 2 sites, and these sites may be the positions of methylation associated with the regulation of gene expression in the subjects studied. Clark et al. (1997) showed that, in mammalian cells, the methylation of external cytosine blocked the binding of certain elements with their corresponding sites and inhibited their function. Therefore, these bands of interest should be investigated in further studies.

\section{DISCUSSION}

DNA methylation is an important modification that affects gene expression through epigenetic regulation involving phenotypic variation and some important agronomic characteristics (Manning et al., 2006; Hauben et al., 2009; Martin et al., 2009). In plant DNA, cytosine methylation leads to gene repression, altering genetic transcription without changing the DNA sequence; consequently, this phenomenon is one of the mechanisms responsible for phenotypic plasticity (Hepburn et al., 1987; Quemada et al., 1987).

Such gene silencing can occur in two ways: directly, whereby DNA methylation alters the binding sites of transcription factors, and indirectly, whereby binding proteins associate with methylated DNA and recruit co-repressors to establish environmental repression of chromatin (Klose and Bird, 2006).

DNA demethylation can occur both passively via the lack of methylation during several cycles of replication and actively in the absence of replication (Zhu, 2009; PonferradaMarín et al., 2010). Active demethylation has emerged as an important mechanism in plant genomes for modulating methylation patterns. Active demethylation may be carried out by either breaking thermodynamically unfavorable carbon-carbon bond links to pyrimidine methyl groups or through a repair process, leading to the replacement of the base $\mathrm{m} 5 \mathrm{C}$ with $\mathrm{C}$ and change in gene expression (Kress et al., 2001; Bird, 2002).

The methylation of cytosine in DNA is generalized in eukaryotes; however, enormous variation occurs in its abundance and genomic distribution and points to de novo methylation and an inversion process of active demethylation of specific sequences (Furner and Matzke, 
2011). Protection against de novo methylation by proteins or chromatin ensures that DNA methylation never reaches a DNA sequence domain. Unmethylated domains can also exist in an active form and remove DNA modification. Working with nuclear proteins involved in the maintenance of genome stability, Baker et al. (2007) concluded that this nuclear proteins expression is directly linked with the active demethylation of DNA, resulting in the activation of epigenetically silenced genes. Recent studies of methylation in seed development in Arabidopsis mutants have reported evidence of loss of methylated CG sites in the endosperm (Gehring et al., 2009; Hsieh et al., 2009). Collectively, these studies suggest that mutation is involved in active demethylation of the maternal genome, giving rise to the endosperm and increasing small interfering RNA production in this tissue (Mosher et al., 2009; Mosher, 2010).

Concluding, the MSAP technique was effective for detecting differentially methylated sites in the genomic material studied, revealing their genetic/epigenetic divergence. Methylation at some sites in the control suggested that the demethylation of genomic polymorphic materials may be responsible for phenotypic variation among different treatments. Bisulfite sequencing should be performed to verify whether these methylation events occur in regulatory genes and therefore to clarify whether methylation and active demethylation are involved in gene regulation.

\section{ACKNOWLEDGMENTS}

Research supported by Fundação de Amparo à Pesquisa do Estado de São Paulo with a Master's scholarship to M.G.F. Rodrigues.

\section{REFERENCES}

Ashikawa I (2001). Surveying CpG methylation at 5'-CCGG in the genomes of rice cultivars. Plant Mol. Biol. 45: 31-39. Baker DE, Harrison NJ, Maltby E, Smith K, et al. (2007). Adaptation to culture of human embryonic stem cells and oncogenesis in vivo. Nat. Biotechnol. 25: 207-215.

Baurens P, Bonnot F, Bienvenu D, Causse S, et al. (2003). Using SD-AFLP and MSAP to assess CCGG methylation in the banana genome. Plant Mol. Biol. 21: 339-348.

Beaulieu J, Jean M and Belzile F (2009). The allotetraploid Arabidopsis thaliana-Arabidopsis lyrata subsp. petraea as an alternative model system for the study of polyploidy in plants. Mol. Genet. Genomics 281: 421-435.

Bernstein BE, Meissner A and Lander ES (2007). The mammalian epigenome. Cell 128: 669-681.

Bird A (2002). DNA methylation patterns and epigenetic memory. Genes Dev. 16: 6-21.

Bird A (2007). Perceptions of epigenetics. Nature 447: 396-398.

Borém A (1997). Melhoramento de Plantas. UFV, Viçosa.

Clark SJ, Harrison J and Molloy PL (1997). Sp1 binding is inhibited by (m)Cp(m)CpG methylation. Gene 195: 67-71.

Dodge E, Ramsahoye BH, Wo ZG, Okano M, et al. (2002). Methylation of MMLV provirus in embryonic stem cells: CpG versus non-CpG methylation. Gene 289: 41-48.

Ferreira EA, Pasqual M and Tulmann Neto A (2009). In vitro sensitivity of fig plantlets to gamma rays. Sci. Agric. Piracicaba 66: 540-542.

Furner IJ and Matzke M (2011). Methylation and demethylation of the Arabidopsis genome. Curr. Opin. Plant Biol. 14: 137-141.

Gehring M, Bubb KL and Henikoff S (2009). Extensive demethylation of repetitive elements during seed development underlies gene imprinting. Science 324: 1447-1451.

Haines TR, Rodenhiser DI and Ainsworth PJ (2001). Allele-specific non-CPG methylation of the Nf1 gene during early mouse development. Dev. Biol. 240: 585-598.

Hauben M, Haesendonckx B, Standaert E, Van Der Kelen K, et al. (2009). Energy use efficiency is characterized by an epigenetic component that can be directed through artificial selection to increase yield. Proc. Natl. Acad. Sci. U. S. A. 106: 20109-20114.

Hepburn AG, Belanger FC and Mattheis JR (1987). DNA methylation in plants. Dev. Genet. 8: 475-493. 
Hsieh TF, Ibarra CA, Silva P, Zemach A, et al. (2009). Genome-wide demethylation of Arabidopsis endosperm. Science 324: 1451-1454.

Jaligot E, Beule T, Baurens FC, Billotte N, et al. (2004). Search for methylation-sensitive amplification polymorphisms associated with the mantled variant phenotype in oil palm (Elaeis guineensis Jacq). Genome 47: 224-228.

Joyce SM and Cassells AC (2002). Variation in potato microplant morphology in vitro and DNA methylation. Plant Cell Tiss. Org. 70: 125-137.

Klose RJ and Bird AP (2006). Genomic DNA methylation: the mark and its mediators. Trends Biochem. Sci. 31: 89-97.

Kress C, Thomassin H and Grange T (2001). Local DNA demethylation in vertebrates: how could it be performed and targeted? FEBS Lett. 494: 135-140.

Li X, Xu M and Korban SS (2002). DNA methylation profiles differ between field- and in vitro-grown leaves of apple. $J$. Plant Physiol. 159: 1229-1234.

Manning K, Tor M, Poole M, Hong Y, et al. (2006). A naturally occurring epigenetic mutation in a gene encoding an SBPbox transcription factor inhibits tomato fruit ripening. Nat. Genet. 38: 948-952.

Martin A, Troadec C, Boualem A, Rajab M, et al. (2009). A transposon-induced epigenetic change leads to sex determination in melon. Nature 461: 1135-1138.

Mason G, Noris E, Lanteri S, Acquadro A, et al. (2008). Polymorphism (MSAP) in identifying genes involved in tomato response to tomato yellow leaf curl sardinia virus. Plant Mol. Biol. Rep. 26: 56-173.

Matthes M, Singh R, Cheah S-C and Karp A (2001). Variation in oil palm (Elaeis guineensis Jacq.) tissue culture-derived regenerants revealed by AFLPs with methylation-sensitive enzymes. Theor. Appl. Genet. 102: 971-979.

McClelland M, Nelson M and Raschke E (1994). Effect of site-specific modification on restriction endonucleases and DNA modification methyltransferases. Nucleic Acids Res. 22: 3640-3659.

Mosher RA, Melnyk CW, Kelly KA, Dunn RM, et al. (2009). Uniparental expression of PolIV-dependent siRNAs in developing endosperm of Arabidopsis. Nature 460: 283-286.

Mosher RA (2010). Maternal control of Pol IV-dependent siRNAs in Arabidopsis endosperm. New Phytol. 186: 358-364.

Peraza-Echeverria S, Herrera-Valencia VA and Kay A (2001). Detection of DNA methylation changes in micropropagated banana plants using methylation-sensitive amplification polymorphism (MSAP). Plant Sci. 161: 359-367.

Pereira FM and Nachtigal JC (1999). Botânica, Biologia e Cultivares de Figueira. In: Cultura da Figueira do Plantio a Comercialização (Corrêa LS and Boliani AC, eds.). 1st edn. FAPESP, Ilha Solteira, 25-36.

Ponferrada-Marín MI, Martinez-Macias MI, Morales-Ruiz T, Roldan-Arjona T, et al. (2010). Methylation-independent DNA binding modulates specificity of Repressor of Silencing 1 (ROS1) and facilitates demethylation in long substrates. J. Biol. Chem. 285: 23032-23039.

Portis E, Acquadro A, Comino C and Lanteri S (2004). Analysis of DNA methylation during germination of pepper (Capsicum аппиит L.) seeds using methylation-sensitive amplification polymorphism (MSAP). Plant Sci. 166: 169178.

Quemada H, Roth EJ and Lark KG (1987). Changes in methylation of tissue cultured soybean cells detected by digestion with the restriction enzymes HpaII and MspI. Plant Cell Rep. 6: 63-66.

Reyna-López GE, Simpson J and Ruiz-Herrera J (1997). Differences in DNA methylation patterns are detectable during the dimorphic transition of fungi by amplification of restriction polymorphisms. Mol. Gen. Genet. 253: 703-710.

Rodrigues MGF, Correa LS and Boliani AC (2009). Caracterização de mutantes da cv. Roxo-de-Valinhos e comportamento de cultivares de figueiras. Rev. Bras. Fruticult. 31: 771-777.

Rodrigues MGF, Correa LS, Tulmann Neto A and Santos PC (2012a). Seleção de clones de figueira cv. Roxo-de-Valinhos formados por gemas irradiadas. Rev. Bras. Fruticult. 34: 1-8.

Rodrigues MG, Martins AB, Desiderio JA, Bertoni BW, et al. (2012b). Genetic characterization of fig tree mutants with molecular markers. Genet. Mol. Res. 11: 1990-1996.

Ruiz-Garcia L, Cervera MT and Martinez-Zapater JM (2005). DNA methylation increases throughout Arabidopsis development. Planta 222: 301-306.

Sha AH, Lin XH, Huang JB and Zhang DP (2005). Analysis of DNA methylation related to rice adult plant resistance to bacterial blight based on methylation-sensitive AFLP (MSAP) analysis. Mol. Genet. Genomics 273: 484-490.

Sherman JD and Talbert LE (2002). Vernalization-induced changes of the DNA methylation pattern in winter wheat. Genome 45: 253-260.

Zhu JK (2009). Active DNA demethylation mediated by DNA glycosylases. Annu. Rev. Genet. 43: 143-166. 